\title{
Writing Artifacts as Narratives of Emotion
}

\author{
KATHLEEN OLMSTEAD \\ The College at Brockport, State University of New York \\ BOBBIE KABUTO \\ Queens College, City University of New York
}

\begin{abstract}
This manuscript will examine the role of emotion in writing through a comparative analysis of home-based written artifacts from children between the ages of 5 and 7 from seven families. We investigate how writing reflects the emotional context of the family that can function as a tool for the construction of narratives. The examination of writing through this perspective illustrates how the process of composing written artifacts reflects the synchronization and coordination of social and historical events imbued with emotions as told by the children's written artifacts.
\end{abstract}

\section{Introduction}

Learning how to compose and construct written messages is a journey of selfdiscovery. Young children not only uncover the linguistic aspects that define writing systems but also learn to become someone in the world. The seminal research on children's writing has shown that long before they are able to control the conventional forms of written language, young children write to explore their social environments through developing knowledge about the functions and purposes of writing (Dyson, 1989, 1993; Taylor, 1983). Moving children's writing away from a global, cognitive perspective, which attempts to document writing development through a linear and progressive model, to a locally, socially, and culturally driven one, researchers have come to acknowledge that as soon as children put writing tools to material they are in the process of organizing their social worlds and writing their identities (Baghban, 2007; Kabuto, 2010). Young writers draw and write about what is most important to them in their immediate social and cultural environment. As young writers grow into more competent writers, they write about relationships with other people in their social worlds through notes, songs, books, and letters (Baghban, 2007; Dyson, 1993; Taylor, 1983).

Although this seminal body of literature provides an extensive foundation that explains the social and cultural nature of early writing, little focus has been paid to the role of emotion in early writing. Drawing from a sociocultural perspective, in this paper, we examine the role of emotion in writing through a comparative analysis of home-based written artifacts from children between the ages of 5 and 7 from seven families. We investigate how writing reflects the emotional context of the family and how writing can function as a tool for the construction of narratives. We use the term written artifact to designate the contextual and temporal nature of writing, as we view writing as artifacts contingent upon context and time (Compton-Lilly, 2014). The examination of writing through this perspective illustrates how the process of composing written artifacts reflects the synchronization and coordination of social and historical events imbued with 
emotions. Within the research presented here, we explore the narratives of emotions, or how emotional content was part of the children's life stories as told by their written artifacts.

\section{Theoretical Foundation}

This study is based on a sociocultural approach to literacy that positions learning and literacy within families as transgenerational processes (Barton \& Hamilton, 1998; Kabuto, 2017; Taylor, 1983). Through this perspective, we argue that knowledge and participation within families are socially and culturally distributed among family members through the reciprocal socialization of learning. Writing, then, is part of literacy because writing is the tool children and parents employ to build relationships with each other and others outside the family. Through a sociocultural perspective, writing is defined as the employment of multiple symbolic forms (i.e., written forms and drawings) that young children use to construct narratives, or patterns of meanings developed through the telling of life stories (Mishler, 1999). This perspective is particularly important for young children who are developing control over the conventional forms of written language. By viewing writing through multiple symbolic forms, we value the diverse ways that young children personally invent written language forms and use drawing to create meaningful messages with family members.

A transgenerational focus replaces the notion of the transmission of knowledge, or how writing practices and concepts are passed from parent to child. Instead, a transgenerational perspective on literacy in families foregrounds the construction and complexity of knowledge over time and space in order to integrate past histories, present experiences, and future possibilities (Compton-Lilly, 2011; Pahl \& Kahn, 2015). As Pahl and Kahn (2015) have illustrated, writing artifacts are carried over generations. Although the artifacts represent a particular point in time, they can be placed in longer timescales, evolving in meaning and purpose with each generation.

At the same time, relationships within the family provide emotional contexts for the social and cognitive growth and development of children. Vygotsky (1986) criticized the separation of cognition and emotion as the separation purports thought processes as an 'autonomous flow of 'thoughts thinking themselves,' segregated from the fullness of life, from the personal needs and interest, the inclinations and impulses, of the thinker" (p. 10). Researchers have argued about the difficulty of defining the term emotion, suggesting that the terms affect, emotion, mood, and personality are used synonymously and interchangeably (Fartoukh, Chanquoy, \& Piolat, 2012; Michell, 2016; Plutchik, 1997). Within this study, emotion is defined as a state, and we prefer to view emotions through the concept of emotional states, which are "transient feelings evoked by a situation" (Plutchik, 1997, p. 18). Emotions, thus, are "hypothetical constructs" (Plutchik, 1997, p. 30) that can evoke feelings, as physiological and biological states (Damasio, 1994). Finally, emotions are social as they communicate and regulate relationships with other people and events in the environment (Michell, 2016).

Few studies have examined young children's writing through the lens of emotion. Fartoukh et al. (2012) studied the role of emotion in the writing process of fourth- and fifth-grade students and found that when students wrote about negative emotions, the students' writing fluidity, determined by the number of words, decreased when compared with writing about positive emotions. That study, along with others (Chenoweth \& 
Hayes, 2003), examined proficient writers during controlled writing tasks. The research presented in this paper, however, extends that previous research to explore the connections between emotion and early writing and examine the interconnections among emotion, the social context of the family, and young writers' motivation to write about relationships with others.

Within written narratives, there is evidence of emotional content that gets communicated with the audience, which may cause an additional emotive reaction from the audience. At the same time, the social context can give rise to particular emotional states, especially as one interacts with others and reacts to events within that context. For instance, when a child writes a birthday card to his or her mother, the mother does not necessarily read the card only once. The mother may revisit the card days, weeks, months, and even years later. The card is a remnant of sociocultural time, or how time reflects the rhythm and patterns of sociocultural events and phenomena (Sorokin, 1943). When a mother revisits the card months or years later, it resurrects memories and emotions that she felt when she saw the card for the first time. The emotions are not a byproduct of the card; they give the card its meaning. Studying the ways in which artifacts carry over generations to maintain narratives of resilience, Pahl and Khan (2015) argued that revisiting artifacts over time is "emotionally complex" as "revisiting is about real lives and trajectories, which carry hope and transformation with them” (p. 120).

While young children are developing writers, who are learning the conventional aspects of written language and developing more complex ways to represent their ideas on paper, the children are engaged in creating what Bamberg and Georgakopoulou (2008) term "small stories," or "how people use stories in every-day, mundane situations in order to create (and perpetuate) a sense of who they are" (p. 379). Telling a parent why they love them, saying sorry for not sharing a toy, or writing a good-bye letter are the small ways that children use situated, purposeful written language to make sense of their lives. Attached to these small stories are larger emotions that become communicated to other people and carry over time and generations as families engage in daily, monthly, and yearly literacy activities. Therefore, the research question in this paper focuses on how the emotional context within the family gives rise to writing events for young writers to generate emotive narratives.

\section{Methodology}

The research presented here is drawn from a 2-year ethnographic study of seven families conducted by the first author (Olmstead, 2015). The study aimed at exploring the literacy experiences of children and families in their everyday home environments in a manner similar to that in Taylor's (1983) Family Literacy to consider how the types and uses of literacy have shifted since the 1983 publication.

\section{The Families}

The participants included seven middle-class families to mirror Taylor's (1983) landmark family literacy study. The families lived in similar suburban areas in a city located in western New York and had children who were 7 years of age or younger at the time of participation (Table 1 provides a description of the families). Following the work of Taylor (1983), the families were considered middle class and had a child who was considered by his or her parents to be learning how to read and write successfully. The 
families had other commonalities including the following: (a) all but one of the families were dual-earner families, relying on both parents to support the family financially, (b) six of the seven mothers had their first child when the mother was classified as "advanced maternal age" (age 35 or older), and (c) 13 of the 14 parents have a high level of education, including bachelor's degrees, master's degrees, and/or doctoral degrees.

Table 1

Overview of the Families

\begin{tabular}{|c|c|c|}
\hline *Family & *Family Members & Descriptions \\
\hline \multirow[t]{3}{*}{ Montgomery Family } & Mother: Valerie & $\begin{array}{l}\text { Valerie is employed as a middle- } \\
\text { school teacher. }\end{array}$ \\
\hline & Father: Phil & Phil is an engineer. \\
\hline & Child: Jason & $\begin{array}{l}\text { Jason is an only child, and was age } 5 \\
\text { at the beginning of the study. Jason } \\
\text { attended Suburban School \#1 and was } \\
\text { part of a neighborhood playgroup } \\
\text { where Olmstead recruited families. }\end{array}$ \\
\hline \multirow[t]{3}{*}{ Maroney Family } & Mother: Michelle & $\begin{array}{l}\text { Michelle, and her husband Gregory, } \\
\text { worked for the same large computer } \\
\text { corporation until } 2010 \text { when they lost } \\
\text { their jobs at the same time due to } \\
\text { downsizing. Michelle remained } \\
\text { unemployed. }\end{array}$ \\
\hline & Father: Gregory & $\begin{array}{l}\text { Gregory found employment working } \\
\text { for the local city transit department. }\end{array}$ \\
\hline & $\begin{array}{l}\text { Children: Ian and } \\
\text { Michael }\end{array}$ & $\begin{array}{l}\text { Ian and Michael are twin boys, and } \\
\text { were age } 5 \text { when the study began. } \\
\text { Both boys attended Suburban School } \\
\# 1 \text { and were part of the neighborhood } \\
\text { playgroup. }\end{array}$ \\
\hline \multirow[t]{3}{*}{ Long Family } & Mother: Jessica & $\begin{array}{l}\text { Jessica is a psychologist who runs her } \\
\text { own practice. }\end{array}$ \\
\hline & Father: Sam & $\begin{array}{l}\text { Sam is employed at a local } \\
\text { corporation and works in technology. }\end{array}$ \\
\hline & $\begin{array}{l}\text { Children: Adam and } \\
\text { Brian }\end{array}$ & $\begin{array}{l}\text { Adam was } 5 \text { at the time of the study, } \\
\text { and attended Suburban School } \# 1 \text {. } \\
\text { Brian was } 2 \text {. The family took part in } \\
\text { the neighborhood playgroup. }\end{array}$ \\
\hline Smith Family & Mother: Kim & $\begin{array}{l}\text { Kim is employed as a middle-school } \\
\text { teacher at the same school where }\end{array}$ \\
\hline
\end{tabular}




\begin{tabular}{|c|c|c|}
\hline & & Valerie teaches. \\
\hline & Father: Tom & $\begin{array}{l}\text { Tom is employed in the field of } \\
\text { telecommunications. }\end{array}$ \\
\hline & $\begin{array}{l}\text { Children: Rachel and } \\
\text { Ryan }\end{array}$ & $\begin{array}{l}\text { Rachel was } 6 \text { years old and attended } \\
\text { Suburban School \#1. } \\
\text { Ryan was } 4 \text { years old during the } \\
\text { study period. }\end{array}$ \\
\hline \multirow[t]{3}{*}{ Bay Family } & Mother: Mary Ellen & $\begin{array}{l}\text { Mary Ellen is employed as a } \\
\text { professor at a local college. }\end{array}$ \\
\hline & Father: Marshall & $\begin{array}{l}\text { Marshall is a musician who plays } \\
\text { professionally, traveling often. }\end{array}$ \\
\hline & $\begin{array}{l}\text { Children: Elizabeth and } \\
\text { Steven }\end{array}$ & $\begin{array}{l}\text { Elizabeth was } 5 \text { years old and just } \\
\text { entering kindergarten at the } \\
\text { beginning of this study. Elizabeth } \\
\text { attended Suburban School \#2. } \\
\text { Steven was almost } 3 \text { and not yet in } \\
\text { preschool. }\end{array}$ \\
\hline \multirow[t]{3}{*}{ Morrell Family } & Mother: Christina & Christina is a stay-at-home mom. \\
\hline & Father: Bob & $\begin{array}{l}\text { Bob is a doctor who is a specialist in } \\
\text { his field. }\end{array}$ \\
\hline & $\begin{array}{l}\text { Children: Alexa and } \\
\text { Ella }\end{array}$ & $\begin{array}{l}\text { Alexa was } 5 \text { and just entering } \\
\text { kindergarten. Alexa attended } \\
\text { Suburban School \#2. } \\
\text { Ella was } 2 \text { and not yet in preschool. }\end{array}$ \\
\hline \multirow[t]{4}{*}{ Walsh Family } & Mother: Karen & $\begin{array}{l}\text { Karen works as an adjunct professor } \\
\text { at a local community college. }\end{array}$ \\
\hline & Father: Tom & $\begin{array}{l}\text { Tom works as a physical therapist in } \\
\text { an outpatient facility of a local } \\
\text { hospital. }\end{array}$ \\
\hline & $\begin{array}{l}\text { Children: Matt and } \\
\text { Hope }\end{array}$ & $\begin{array}{l}\text { Matt was } 6 \text { and in the first grade. He } \\
\text { attended Suburban School \#1. } \\
\text { Hope was } 4 \text { and in preschool. The } \\
\text { family were part of the neighborhood } \\
\text { playgroup. }\end{array}$ \\
\hline & Grandparent: Grammy & $\begin{array}{l}\text { Grammy took care of Matt and Hope } \\
\text { while their parents are working. }\end{array}$ \\
\hline
\end{tabular}

*All family and first names are pseudonyms. In order to maintain confidentiality of the children, names were removed from the writing samples presented in this paper. The focal children were all considered successful young readers by the families and the schools.

Collected Data 
The data collected for this study focused on observations, interviews, and the collection of written artifacts by the parents and their children. In the following, we describe the landscape of the collected data.

Observations. Data collection began with observations of the family within the home. Each week, Olmstead visited at least one family, resulting in approximately one visit every 6 weeks per family over the 2 years of the study. Observations were conducted at various times (afternoon, evening, play, homework time, etc.), working within the schedule of each family. Ethnographic observations were documented utilizing thick description (Glesne, 2010). During the observations, Olmstead examined family interactions and practices, such as family members reading, writing, painting, or playing together and children interacting with each other, as well as with computers and other technologies. The observations took place during 2010 and 2011.

Interviews. In addition to ethnographic notes, more than 30 hours of audio and video data were recorded. The audio and video data include family interviews or what Taylor (1983) called focused conversations. These focused conversations were conducted by incorporating a modified version of "life story" research (Brandt, 2001) by encouraging open-ended autobiographical monologues. At each home visit, the interviews started with open-ended questions. Olmstead inquired into how the family was doing without purposefully guiding the conversation. The goals of the interviews were to give the parents a voice and agency in determining the direction of the conversation. Before each home visit, the data were analyzed for emerging themes. If family members did not initiate their own focus for the conversation, then emerging themes were used to prompt conversations. Some of these emerging themes centered on the families' feelings about the use of technology, the disconnections between home and school literacy practices, and the demands of family, work, and school.

Collection of written artifacts. Written artifacts were collected at each home visit, resulting in a total of 300 written artifacts. These artifacts were collected in two ways. First, families engaged in literacy digs (Taylor, 1983) to assist with collecting written and other artifacts. Olmstead was often taken to areas of the home where children's work was displayed or stored. Parents' literacy artifacts were captured when posted around the house or in some cases when emails, letters, or personal electronic notes and other writings were voluntarily shared.

The second means of artifact collection occurred when the children were engaged in writing or drawing activities during Olmstead's visits. Photographs or portable scans of these artifacts were taken, and conversations with children about their artifacts were audio-recorded or documented through note taking. Written artifacts included those created through technology (such as through email) or searches on search engines (such as Google) and those created by physical materials, such as paper, pencils, crayon, and cardboard.

For this analysis, we included written artifacts that met the following criteria: (a) self-created, (b) resulted from emails and physical materials, including printed-out notes, letters, cards, or signs, and (c) produced when the children in the study were in kindergarten or first grade. In addition to excluding computer searches, we excluded 
self-portraits and artifacts that had only a written name, unless we had observational data that described the intention of the writer. Without documentation to link to an emotion, we left the artifact out of this analysis, which specifically focused on emotion. In addition, the children created a number of books. For the analysis, we analyzed 15 books. In order to employ simultaneous coding to capture the complex meanings represented in the books, we coded the book as one artifact and the pages separately. The books ranged from one to 14 pages (including the covers), with a total of 72 pages across the 15 books. Therefore, we examined a total of 128 out of the 300 total artifacts, which includes the books as one artifact. When the individual book pages are included, we analyzed 200 written artifacts.

\section{Data Analysis}

The data analysis consisted of cross-case and within-case analyses, which enhanced the richness of the data and findings, as well as allowed us to "strengthen the precision, validity, stability, and trustworthiness of the findings" (Miles, Huberman, \& Saldana, 2013, p. 29). For the analysis described below, our beginning unit of analysis was at the family level. As with ethnographic research, the purpose, however, is not to generalize the findings to all families. Instead, by examining the cases as a whole, we could elucidate themes that cut across the case studies and at the same time, pinpoint deviations in the data and data analysis for each family. We employed two main analyses for the cross-case analyses: grounded theory and content analysis.

Grounded theory. Within ethnographic studies, data collection and analysis are not discrete processes but often take place simultaneously (Heath, Street, \& Mills, 2008). Through grounded theory, the observations and interviews were analyzed for themes that described the social and economic context of the families. These themes were critical for contextualizing the written artifacts created by the families. Through the development of the themes, the role of emotion came to the forefront of the analysis. As families expressed happiness or dealt with grief and stress, we explored how the children's artifacts mirrored these emotions or questioned whether the artifacts existed on the fringes of the emotional context within which the family lived. Based on this analysis, we formed two questions that guided our analysis of the role of emotion in children's writing. These questions are the following: (a) What types of emotive narratives were supported or challenged by the written artifacts? (b) How did emotions play roles in motivating children's writing within the context of the family?

Content analysis. To address the research questions, we used a content analysis in which we coded each artifact for the emotive content. Before the coding, we created a description for each artifact that contextualized it within the lives of the children by using the observational and interview data.

After creating the descriptions, we coded each artifact based on the following questions: (a) Location: Where was the artifact written? (b) Content: What is the artifact about? (c) Materials: What was the media of dissemination? (d) Emotion: What emotional state is attached to the artifact? The development of the concept codes that addressed each question required multiple reviews of the artifacts and descriptions. The concept codes were collapsed to form a larger thematic code. Table 2 presents the 
thematic and concept codes, and the total number of codes that resulted from the analysis. We used simultaneous coding, which employs two or more codes to a single artifact (Saldaña, 2016). Artifacts, such as books or cards, may have had multiple meanings that require more than one code. In order to analyze the multiple meanings, we broke down the artifact into smaller units, like pages, sections, and text segments, and coded each unit. We found that coding each segment better captured the complexity of the emotional content communicated within the artifacts.

Table 2

Number of Thematic and Concept Codes

\begin{tabular}{|c|c|c|c|}
\hline Focus area & Thematic Code & Concept Codes & $\begin{array}{c}\text { Total Number of } \\
\text { Codes }\end{array}$ \\
\hline \multirow[t]{5}{*}{ Location } & \multirow[t]{3}{*}{ Home } & Home & 97 \\
\hline & & Family trips & 4 \\
\hline & & Total & 101 \\
\hline & \multirow[t]{2}{*}{ School } & Classroom & 27 \\
\hline & & Total & 27 \\
\hline \multirow[t]{23}{*}{ Content } & \multirow[t]{9}{*}{ Animals } & Bats & 1 \\
\hline & & Bears & 1 \\
\hline & & Butterflies & 1 \\
\hline & & Dogs & 1 \\
\hline & & Ducks & 3 \\
\hline & & Fish & 1 \\
\hline & & Geese & 1 \\
\hline & & Owls & 1 \\
\hline & & Total & 10 \\
\hline & \multirow{11}{*}{$\begin{array}{l}\text { Childhood pop } \\
\text { culture }\end{array}$} & Cars & 1 \\
\hline & & Arts and Crafts & 2 \\
\hline & & Filmstrips & 3 \\
\hline & & Games & 4 \\
\hline & & Food & 1 \\
\hline & & Library & 1 \\
\hline & & Playground & 2 \\
\hline & & Rockets & 16 \\
\hline & & Shapes & 1 \\
\hline & & Video game characters & 2 \\
\hline & & Total & 33 \\
\hline & \multirow[t]{3}{*}{ Family } & All family members & 14 \\
\hline & & Mom & 2 \\
\hline & & Dad & 3 \\
\hline
\end{tabular}


House 5

Sister 1

Brother 3

Grandmother 1

Grandfather 1

Total 30

Friends $\quad$ Friends’ names 3

Playdates 2

Total 5

Seasonal Halloween $\quad 1$

Holiday wish 2

Pumpkin farm 1

Snow 2

Valentine 1

Total 7

Materials $\quad *$ Books $\quad$ ABC book

All About Me books $\quad 1$

Animal books 4

Pool book 1

Trip books 3

Illness books 1

Family books 4

Total 15

Communicational Votes 1

materials $\quad$ Letters 1

Banners 1

Cards 5

Emails 1

Lists 4

Labels 1

Notes $\quad 15$

Maps 1

Postcards 2

Signs 8

Survey 3

Total 42

$\begin{array}{lll}\text { Emotions } & \text { Positive } & 186\end{array}$

Love and affection $\quad 123$

Curiosity 3

Satisfaction $\quad 15$

Impressiveness 3 
Comfort

Empowerment

Surprise

Total

Negative
Grief and loss

Frustration

Sickness

Sadness

Guilt

Total

*In order to consider the multilayered meanings of the books, the books were coded as one artifact and the pages were coded separately for the pages' emotional content. A total of 72 pages were coded across the 15 books.

Because we define emotions as complex states of physiological and biological feelings used to communicate and develop social interactions within the context of the family, we recognize the difficulty of using codes to package particular types of emotional states, such as happiness or sadness. Table 3 provides descriptions of the codes used to frame the emotions that were part of the artifacts in this study. The emotions described in Table 3 were divided further into two categories: positive and negative emotions. The use of positive and negative emotions builds on the work of Dix (1991), who studied the role of emotion in parenting. The use of the terms positive and negative indicate a "barometer" in relationships (Dix, 1991, p. 19), rather than extreme or fixed states. Although we categorize an emotion as a negative or positive one, these emotional states communicate meaning to others. For instance, grief and loss are negative emotions because they are the result of negative experiences. In reacting to this emotional state, parents may show love as a way of responding to children's needs. Rather than viewing these emotional states as discrete categories of positive and negative, we view them as a dynamic system of coordination of interactions among family members.

Table 3

Definitions and Characteristics of Emotions Used in This Study

\begin{tabular}{ll}
\hline Emotions & Defining Characteristics from Children in This Study \\
\hline Enjoyment & $\begin{array}{l}\text { Defined by a state of pleasure and joy. The result of this emotional } \\
\text { state is the desire to engage in repeated activity with people, such } \\
\text { as playing and creating games or talking with friends. } \\
\text { Love and Affection } \\
\text { Defined by a state of deep interpersonal affection, attachment, or } \\
\text { endearment. The results of this emotional state are often } \\
\text { communicated by unconditional bonds of attachment. } \\
\text { Defined by a state of wanting to learn more, asking questions, or }\end{array}$ \\
\hline
\end{tabular}




\begin{tabular}{|c|c|}
\hline & $\begin{array}{l}\text { wanting to observe cause-and-effect relationships. The results of } \\
\text { this emotional state are questioning or researching topics, such as } \\
\text { conducting Internet research. }\end{array}$ \\
\hline Satisfaction & $\begin{array}{l}\text { Defined by a state of contentment or fulfillment. The results of this } \\
\text { emotional state are receiving a response that children wanted from } \\
\text { their families or environments. }\end{array}$ \\
\hline Impressiveness & $\begin{array}{l}\text { Defined by a state of being awestruck or admired. The results of } \\
\text { this emotional state are sounding or looking surprised or } \\
\text { expressing a sense of disbelief. }\end{array}$ \\
\hline Comfort & $\begin{array}{l}\text { Defined by a state of ease or relaxation. The results of this } \\
\text { emotional state are feeling relaxed after a problem has been solved } \\
\text { or taking solace when a negative event is anticipated. }\end{array}$ \\
\hline Empowerment & $\begin{array}{l}\text { Defined by a sense of taking power for oneself. The results of this } \\
\text { emotional state are responding to an event or person who feels } \\
\text { oppressive. }\end{array}$ \\
\hline Surprise & $\begin{array}{l}\text { Defined by a state of shock. The results of this emotional state are } \\
\text { expressing a feeling of disbelief or astonishment about an event } \\
\text { that has happened in the environment. }\end{array}$ \\
\hline Grief and Loss & $\begin{array}{l}\text { Defined by a state of sorrow at the loss of someone or something } \\
\text { in the environment. The results of this emotional state are } \\
\text { expressing distress or heartbreak at an event that has caused the } \\
\text { loss of something or someone. }\end{array}$ \\
\hline Frustration & $\begin{array}{l}\text { Defined by the state of annoyance. The results of this emotional } \\
\text { state are sounding angry at not being able to do something or act } \\
\text { in a way that one wants to act. }\end{array}$ \\
\hline Sickness & $\begin{array}{l}\text { Defined by the state of being ill or physically uncomfortable. The } \\
\text { results of this emotional state are feeling down or slow, having } \\
\text { low energy, or being sleepy so that one does not want or have to } \\
\text { engage in regular activities. }\end{array}$ \\
\hline Sadness & $\begin{array}{l}\text { Defined by the state of unhappiness or disappointment. The results } \\
\text { of this emotional state are wanting to be by oneself or not wanting } \\
\text { to engage in activity. }\end{array}$ \\
\hline Guilt & $\begin{array}{l}\text { Defined by the state of feeling responsible for something that went } \\
\text { wrong. The results of this emotional state are wanting to apologize } \\
\text { or admit to an action that had an unwanted consequence. }\end{array}$ \\
\hline
\end{tabular}

We examined the data in two main ways. First, we analyzed the codes as described in Table 2 in order to compare the numbers for the location, content, materials, and emotional content across all the artifacts. Second, we analyzed the artifacts by family by running cross-tabulations between the family and the coded artifacts to look for internal patterns. This analysis assisted in developing a family profile. Because our initial unit of analysis was at the level of the family, there are two limitations in comparing the number of artifacts across families. Not all of the families had the same 
number of individuals. For instance, five out of the seven families had two children, one family had one child, and one family had three children, although one child was not born at the start of the study. The differing number of family members may have impacted the total number of artifacts collected. Although we recognize this limitation, we also are cautious to make the assumption that more children may result in more artifacts. The number of artifacts collected is reflective of the family profile at the time of the study, and this profile is not influenced only by the number of children. The profile is also impacted by the social and emotional context of the family. Furthermore, because we are comparing artifacts across families, individual children's artifacts are not analyzed as a single case. For instance, particular children within the family may have been more engaged in communicating through writing or more focused on particular types of content. Although this analysis is another way of examining the data, it is not the focus of this paper.

After the cross-tabulations were completed, we triangulated the content analysis with the observations and the interviews. Below, we present the findings, and instead of focusing on the numerical data from the cross-tabulations, we present the overall themes that addressed the two research questions.

\section{Findings}

Based on the content analysis, the majority of the written artifacts were produced in the home (Table 2). Coming from middle-class homes, the children had access to various materials, ranging from crayons to paint to window markers, and the freedom to produce a range of messages that the structure of school did not offer. Based on Table 2, the children within the study created two main types of media to disseminate their messages. The largest type of artifacts that appeared were communicational materials. The children wrote notes to their parents or grandparents. In addition, the children wrote and posted signs asking younger siblings to keep out of their room or play space or inviting people to enter. Birthday and thank-you cards, apology letters, maps, and lists also composed this category of writing. The second type of media that appeared were books. The children wrote and drew about a variety of content. The largest category of content included childhood and pop culture materials, such as rockets, video game characters, going to the library, and playing games. In addition to childhood and pop culture items, the artifacts included family members. The children wrote notes and created books and signs addressed to their mothers, fathers, siblings, and grandparents. A fewer number of artifacts focused on animals, friends, and seasonal topics, such as holidays. Positive emotions, which included enjoyment, love and affection, curiosity, and satisfaction, dominated the content of the written artifacts. Negative emotions, which included grief, frustration, sickness, and sadness, appeared far less frequently. In the following, we return to the two research questions to address the types of emotive narratives and how emotion motivated the children's writing in the context of the family.

\section{Types of Emotive Narratives}

The three main categories of emotive content that appeared in the artifacts centered on enjoyment, love and affection, and grief and loss (Table 2). When emotive content was compared to the topical content of the artifacts, the artifacts that addressed childhood and pop culture items communicated a sense of enjoyment and excitement. As 
an example, Ian and Michael from the Maroney family and Matt and Hope from the Walsh family role-played a game they called "Mario," a version of their favorite video game Nintendo Super Mario Bros. in which they pretended to be different characters and chased one another around the house. One of the children mentioned "old fashion Mario," the 1980s version of the video game character. The children began to wonder what "old fashion Mario" looked like and immediately gathered around the computer to search for "old fashion Mario." After finding images of the 1980s version of Mario, the children were struck by the difference in images but not because the two Mario's looked significantly different. Instead, the children noticed that the 1980s Mario looked like pixels. Ian commented, "Instead of real people, they're pixels. It's weird." Michael replied, "You can hardly see what they are (with pixels)." The fascination with Super Mario crossed to other games, leading to the creation of "Super Angry Birds." The children created signs with "Bubble Bird" and other types of characters. By creating Super Angry Birds signs on paper, the children were able to make the game real and playable by other children.

At the same time, emotive content related to enjoyment was communicated through communicational materials, such as signs, lists, cards, and banners. On one visit, Olmstead observed the large Happy Birthday banner that Michael created to celebrate a family member's birthday. Jason from the Montgomery family had a special interest in rockets because shooting off rockets was one of his favorite pastimes with his dad. Interpreting this real-life experience on paper, Jason regularly drew different types and colors of rockets, while naming them with unique names, such as Super Mega, Neon Streak, XL, Apple, Big Daddy, and Victor (Figure 1).

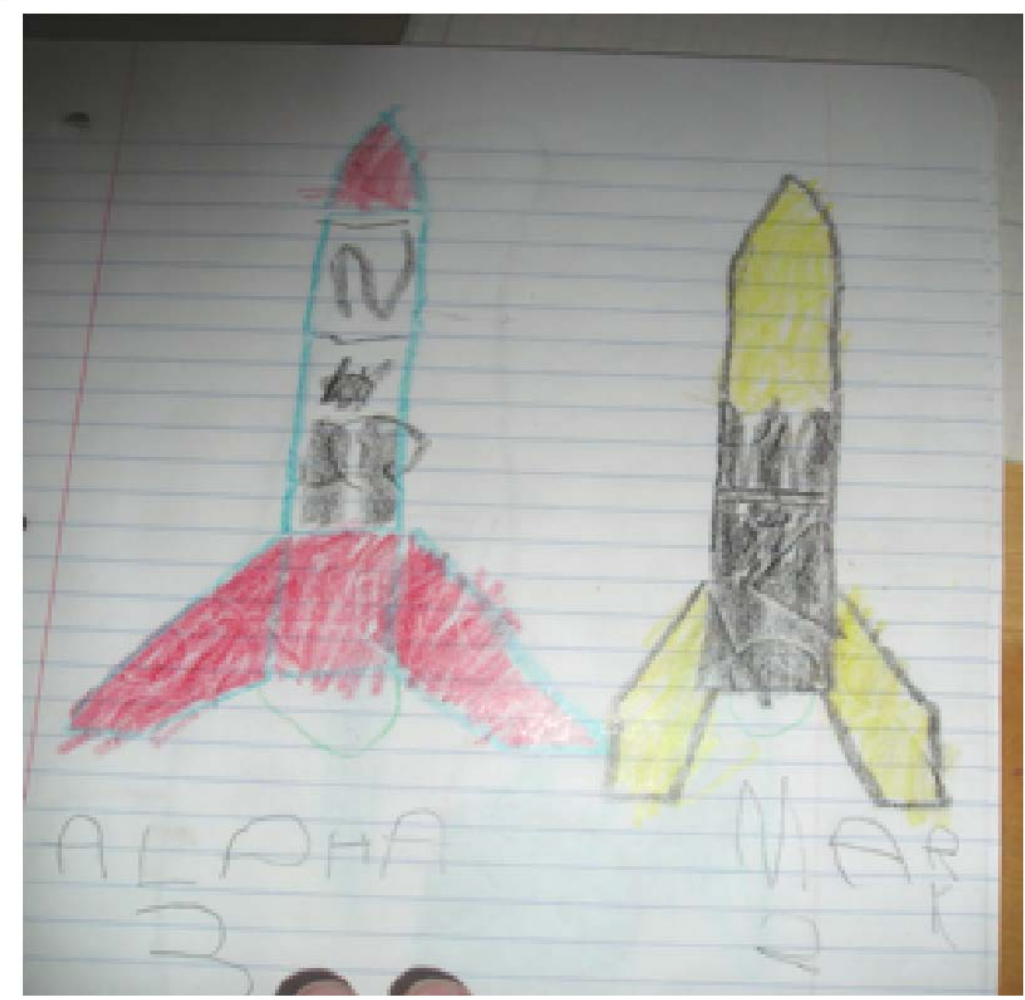

Figure 1. Jason's drawing of rockets. 
The emotive content that appeared with the second greatest frequency across the artifacts in this analysis reflected emotions of love and affection. Writing and drawing were ways for children to build and reinforce positive relationships with the other people, places, and things in their immediate home environment, and the focus on family, including family members, pets, and items, took a natural focus in the children's artifacts. Figure 2 provides an example, in which Hope from the Walsh family wrote Riley, her new pet dog, a letter expressing her affection toward her as the newest member of the family. Hope, who was in kindergarten, wrote:

Dear Riley,

You are the best girly dog in the world. Thank you for not barking to the cat.

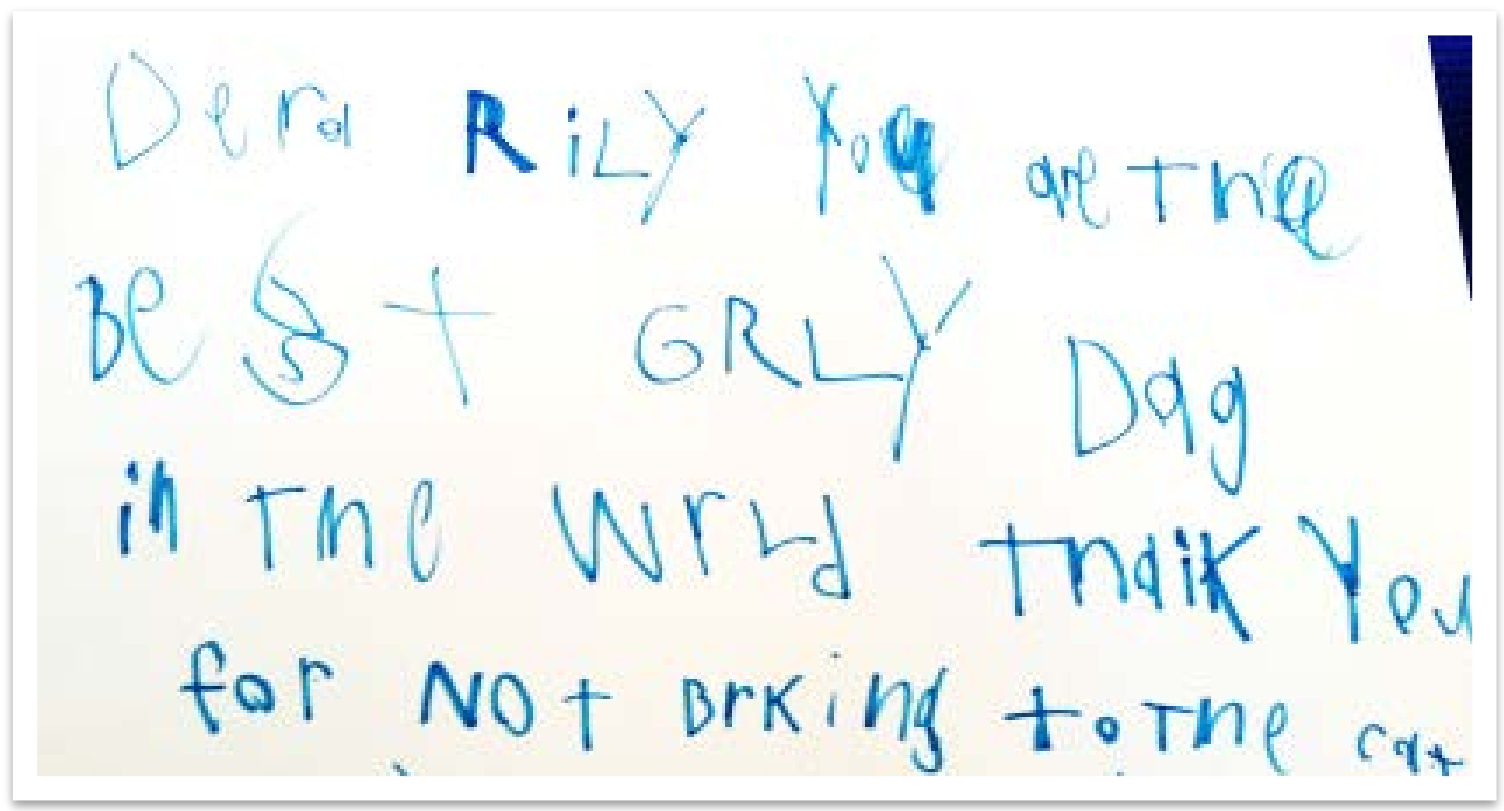

Figure 2. Hope’s letter to Riley.

These types of expression of love on the part of the children were communicated mainly through communicational materials. Love notes were a predominant means for expressing their love and affection. Children, such as Alexa from the Morrell family and Hope, wrote the common phrase I love you, , with mom, dad, or a sibling's name filling in the blanks. They often included drawings of hearts and other types of items of adoration. In addition to communicational materials, the children wrote books about family members or to family members.

Although far fewer when compared to family, friends were also the object of affection for many of the children in the study. Elizabeth from the Bay family wrote and drew a series of pictures of her family and friends, and Adam from the Long family wrote his friends' names on one of his living room windows with window markers.

Grief and loss were the negative emotions that appeared with the highest frequency within the artifacts in this analysis. An example of such an artifact came from Hope. After the family adopted Riley, she became featured in many of Hope's writings and drawings around the house. Soon after adopting Riley, Hope was horrified to see 
that Riley had hunted a baby rabbit in her backyard. Traumatized by the death of the rabbit, Hope could not talk about what she had observed, saying "It's too sad to talk about.” About a week after the incident, Hope wrote a story in school about the event and brought it home. Figure 3 shows the first page of the story. The entire story read:

Title: "Dead Baby Bunny"

Page 1: "One day Riley and Matt and me well we goed outside".

Page 2: "Riley saw a bunny. It was a baby. She was chasing it".

Page 3: "And she was so close, she just grabbed it in her mouth. Poor baby bunny I said”.

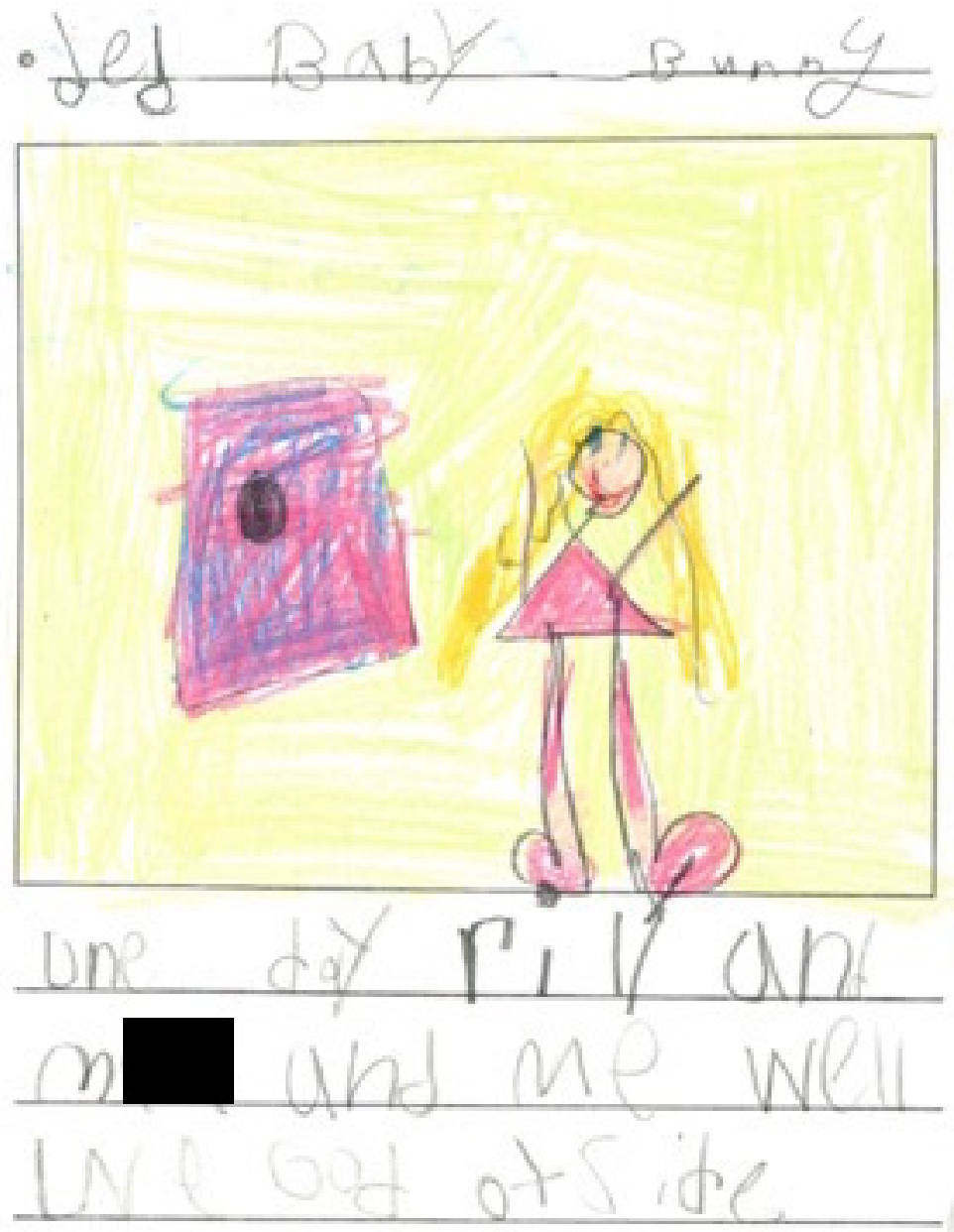

Figure 3. The first page of Hope's story about the dead baby bunny.

Hope drew a picture on each page of the book to match the story on the page. When asked about the story, Hope said:

I just wanted people to know about my feelings. I read it to my teacher and she told me, "Well, sometimes that happens." She said it was a good story. I felt a little better because I get to tell people about it so they know how sad I feel. 
In another example, Michael from the Maroney family wrote a letter to his grandfather who passed away when Michael was in kindergarten. Michelle found the letter in Michael's room and encouraged him to read it at the funeral services. Michael wrote:

All the smiles he gave to other people. And how good and helpful he was. And he was such a good man. And I miss playing games with him. He could only play a game 'cause he couldn't get down (on the floor to play). I love you papa.

Hope's and Michael's stories were critical for the children to strategically communicate and negotiate relationships with members of their families (Plutchik, 1997). Hope was not comfortable talking about what she saw. By creating her interpretations of the events on paper, however, Hope felt in control about how and when to speak and express her feelings. Michael wrote this letter in his solitude unbeknownst to others to work through his sense of loss.

\section{Role of Emotion in Motivating Writing within the Context of the Family}

Findings from the cross-case and within-case analyses illustrate that while the types of positive and negative emotions were spread across the families, particular emotions dominated within different families. A more detailed look into each case illustrates how the emotional states were reflective of the events that were happening in the family and the larger context within which the families were living. These events and the emotive context motivated the children in the study to write and draw, and their writings and drawings reflected or were a reaction to the emotive context.

Table 4

Emotions and Number of Codes by Family

\section{Family}

\begin{tabular}{lccccccc} 
Type of Emotion & Bay & Long & Maroney & Walsh & Montgomery & Morell & Smith \\
\hline Grief and Loss & 15 & 0 & 3 & 3 & 0 & 0 & 0 \\
Enjoyment & 18 & 15 & 39 & 9 & 78 & 15 & 12 \\
Love and Affection & 21 & 9 & 18 & 33 & 15 & 21 & 6 \\
Frustration & 3 & 0 & 0 & 6 & 0 & 0 & 0 \\
Curiosity & 0 & 3 & 0 & 0 & 0 & 0 & 0 \\
Satisfaction & 0 & 9 & 6 & 0 & 0 & 0 & 0 \\
Sickness & 0 & 0 & 3 & 0 & 0 & 0 & 0 \\
Sadness & 0 & 0 & 0 & 0 & 3 & 0 & 0 \\
Impressiveness & 0 & 0 & 0 & 0 & 0 & 3 & 0 \\
Comfort & 0 & 0 & 0 & 0 & 0 & 3 & 0 \\
Empowerment & 0 & 0 & 0 & 9 & 0 & 0 & 0 \\
Surprise & 0 & 0 & 0 & 3 & 0 & 0 & 0 \\
Guilt & 0 & 0 & 0 & 3 & 0 & 0 & 0 \\
\hline Totals & $\mathbf{5 7}$ & $\mathbf{3 6}$ & $\mathbf{6 9}$ & $\mathbf{6 6}$ & $\mathbf{9 6}$ & $\mathbf{4 2}$ & $\mathbf{1 8}$ \\
\hline
\end{tabular}


Table 4 presents the types of emotions and number of codes for each family. Jason's artifacts in the Montgomery family tended to reflect a sense of enjoyment because of his love of rockets (Figure 1). Jason and his dad enjoyed making and shooting off rockets in the backyard and at local rocket launches. Jason created numerous rocket signs, pictures, and names, 15 of which are represented in this analysis. Jason's love of rockets was not necessarily about the rocket itself as a neutral object. Instead, we suggest, his interest in rockets was a result of how rockets mediated the positive relationships he had with his mom and dad.

During this study, Jason's father Phil faced greater demands and stress at work as a result of the economic downturn in the mid-2000s. Due to work demands and financial pressure on the family, Phil spent an increased amount of time outside the house. This changing dynamic in the family caused Jason to miss his father and the activities, which included playing Legos and riding bikes, that they shared. Before Phil left the house one morning, Jason wrote a sign that said, "Please come home early" and posted it on the front door. The children's artifacts reflected the various emotions represented in the family and challenged them. Thus, as Jason's note asking his dad to come home earlier communicated a certain sadness about the changing dynamics in the family that Jason felt negatively affected him, Jason's increased drawing and writing about rockets countered that sadness. In other words, by returning to his love of rockets, he was able to relive the joy in an imaginary space each time he wrote, drew, and named rockets.

Love and affection dominated artifacts in the Walsh family. Grammy (the children's grandmother) was often present in the home babysitting Matt and Hope while their parents were working. Matt, for example, wrote a book about Grammy. In the book, created with story paper, a pencil, and crayons, Matt drew pictures of Grammy and wrote the following:

Page 1: Do you know what my wish is? I wish my grammy was here.

Page 2: Because she makes me have ... ?

Page 3: Do you know how much I love her? Passed heaven and back.

Page 4: I wish she would come today.

Matt's book shows the duality of emotions that occur within written artifacts. On the one hand, Matt's book denoted the sense of love he had for his grandmother, a feeling magnified by the fact that his grandmother was not coming to visit that week. Matt's sentence, "I wish my Grammy was here" and the phrase that he loved her "passed heaven and back" communicated a sense of sadness because he would miss his grandmother. Between those two sentences, Matt asked the question, "Do you know how much I love her" to demonstrate the fondness that he has for his grandmother. Matt's book is the result of his developing resiliency toward missing a loved one, or that a positive emotion can counter a negative one as each contributes to the development of a balanced state between individuals (Plutchik, 1997).

Feelings of grief and loss were represented more frequently in the artifacts by the Bay family. The Bay family had a babysitter, Sarah. Lists and charts outlining rules and expectations, as well as predetermined consequences for behaviors deemed unacceptable, were found around the house and helped Mary Ellen and Sarah manage everyday life. 
Sarah, however, could not find a full-time job due to economic conditions in the area and needed to move out of state. Sarah, therefore, left her position with the Bay family. Shortly after Sarah moved, Elizabeth drew signs with pictures of a house for sale and wrote, "Sarah is moving" and "Sarah had a beautiful house." Mary Ellen described how she found these stories throughout the house and believed these signs were Elizabeth's way of working through this challenging loss, although she did not directly talk about it. Without these artifacts, Mary Ellen may not have been privy to the emotional struggle that Elizabeth was going through. In turn, Elizabeth's artifacts, similar to Jason's, were a direct consequence of her trying to understand the changing dynamics of the family. While Jason's artifacts focused on his sense of enjoyment of activities that brought him and his dad together, Elizabeth's artifacts focused on a sense of loss. In another artifact, Elizabeth drew an empty house and wrote, "A friend's house for sale." The feelings of emptiness and loneliness and the changing relationships within the family created the emotional context that Elizabeth attempted to understand and negotiate. Elizabeth's artifacts, as well as Jason's, Matt's, and Hope's, made the children's feelings real and concrete for themselves and their families.

\section{Discussion}

The findings illustrate how writing was a tool for conveying emotions that resulted from particular sociocultural events within the family, and the children in the study used writing as a way of responding and reacting to those various events and the emotional contexts within the home. The various samples presented illustrate how the families used texts to participate in the "multiplicity of literate activities" by engaging in diverse social practices in the home (Taylor, 1983, p. 54). For example, the children in this study played office by setting up a desk to create surveys and do their "work." Several of the parents have home offices littered with "important" paperwork that may have provided a model for the children. The children sent secret notes and messages from one place to another. The children also celebrated important days and maintained relationships by making signs, cards, and notes. Bomer and Maloch (2012) suggested that what may appear to be mundane activities are critical for children and argued that children "do literacy situated within other doings, not as something detached from life, on special pieces of paper for 'practicing' writing” (p. 46). The artifacts used for this analysis evolved out of these practices and created small stories that carried and communicated various emotions because they were attached to children's authentic life experiences.

The creation of a large number of artifacts focused on positive emotions over negative ones as a way of making sense of family life experiences is supported by a body of research that contends writers write more about positive emotions compared with negative emotions (Burton \& King, 2004). Focusing on older, experienced writers, studies have shown that when writers write about positive experiences the writers use language that reflects an enhanced sense of self and are more insightful into and attentive toward their writing (Fredickson, 1998). Extending the research to younger writers, the findings of this study suggest that the children expressed positive emotional experiences in their writing, such as building relationships with family members, playing games, or recalling favorite animals or objects during trips, over negative ones. 
Writing artifacts representing negative emotions appeared far less frequently than artifacts that communicated positive emotions but served important purposes in helping the children work through stressful or traumatic events. Hope's story about the dead baby bunny, Elizabeth's signs about the loss of her babysitter, Michael's letter about the death of his grandfather, and Matt's book about his grandmother illustrate the doublevoicedness and duality of emotions within authentic artifacts that address love and grief. The Bakhtinian concept of dialogism describes how writing is double-voiced; at least two voices are present in a writing piece, that of the writer and that of the listener (Holquist, 1981). While artifacts represented negative emotions, such as grief, loss, and sadness, other emotions countered the negative emotions, such as love and forgiveness. In other words, at least two emotions worked in conjunction with each other: one that the writer felt because of the event and one that the writer felt toward the topic (person or thing) within the event. This point connects to Plutchik's (1997) argument that emotional states are "transitory adjustment reactions that function to return the organism to a stable, effective relationship with its immediate interpersonal environment when that relationship is disrupted" (pp. 20-21). The duality of emotional states represents, on one level, the child and on another level, his or her sociocultural environment. Writing, thus, was the tool with which to engage in the complex relationships between self and the environment (Michell, 2016).

Additionally, studies suggest writing about traumatic events and adjustment to changing relationships has mental health benefits. Although researchers have shown that written artifacts that address negative events are qualitatively different from written artifacts that express positive emotional states, researchers have contended that there are important biological and psychological benefits of writing stories about negative events that occurred within one's life history (Burton \& King, 2004). King and Miner (2000) found that writing about negative events required writers to self-regulate their emotions. King and Miner (2000) explained, "Writing about the positive aspects of a negative event may spur self-regulatory processes that allow the individual to deal effectively with the emotion caused by the experience” (p. 227). Similar to King and Miner's findings, this study showed that children, like Hope, who wrote about negative events with evidence of positive emotions were provided the opportunity to "confront, control, and structure thoughts and feelings of traumas without having to deeply re-experience or experience the event itself” (King \& Miner, 2000, p. 227). King and Miner (2000), as well as other scholars (Burton \& King, 2004), made this argument about older writers. The present study extends those findings to young early writers to suggest that young children may have a desire to recreate interpretations of negative life events through writing in different symbolic forms (i.e. writing and drawing). In other words, neither conventionality in writing nor the sole dependence on written forms was a necessity for the children in this study to communicate ideas in response to events or people the children experienced in their environment (Michell, 2016). Therefore, these artifacts represented what Pahl and Khan (2015) call “artifacts of resilience” (p. 121).

Artifacts of resilience are objects that communicate meanings of resiliency across generations, or transgenerationally, within literacy practices embedded in the family. To better understand the notion of carrying meanings transgenerationally, it is critical to discuss the value of timescales in understanding children's stories that express emotions. A writing event, such as Elizabeth's act of drawing her sign of Sarah's house or Hope's 
letter to Riley when she first came to the family, occurred on a short timescale. The children in the study wrote in fleeting moments, sometimes unbeknownst to the parents, taking 1 to 2 minutes, or 1 or 2 days. While the actual event was on a short timescale, the relationships represented within the artifacts occurred over longer timescales, perhaps from the time the children were born. While Michael wrote his letter to his grandfather within a short timescale, Michael's relationship with his grandfather developed over a longer one, and both were embedded in the locality of the family. The representation of grief over losing his grandfather represented a recent event, but the emotive aspect of love and affection developed over a longer scale that included repeated and varied shorter events that unfolded within social practices. Together, these events built a relationship between grandfather and grandson. Researchers have advocated for the important relationships that family members across generations have for supporting and developing literacy practices in the home (Gregory, Long, \& Volk, 2004).

Therefore, within the family, children's small stories as told by their artifacts represented events, and the repeated stories told over many different artifacts over longer timescales developed into larger narratives of emotions: narratives of grief at losing a family member, narratives of love and affection among family members, and narratives of enjoyment at building relationships with other people. These narratives transcended the generations in two ways. First, the narratives included relationships with family members who were members of previous generations, such as Matt's book about his grandmother. Second, the narratives took on renewed meanings as different generations read and interpreted the stories. For example, Elizabeth wrote and drew about her babysitter leaving with a sense of loss. Mary Ellen, however, interpreted Elizabeth's story not as a despondent one but instead as one that Elizabeth elected to complete in order to better understand the changes in her life and to articulate and expand her understanding of herself within the family. It can be argued that Mary Ellen developed a counternarrative as she transformed the artifact to create alternative meanings.

Learning to write in the authentic context of the family means developing meaningful life stories that create larger narratives of emotions that are carried over timescales and generations. The desire to connect to the positive narratives of emotion not only motivated children to write and explore language forms and communicational media but also created a way to address the positive and negative changes that impacted the children's lives.

\section{Conclusion}

Written artifacts are the result of children's constructions of narratives of emotion that give a voice to their family stories as the children engage in real and purposive literacy activities within the context of the family. Because this study did not investigate writing within the context of school, further research that investigates how young children negotiate the boundaries of home and school through writing as emotive narratives is warranted. Hope provided a look into this negotiation when her stories of the dead baby bunny moved across the context of home and school, and between teacher and parent. As Murray (1991) stated, "Writing is an act of therapy and an act of power . . . Our students have important messages to deliver and their own language in which to deliver them” (p. 6). With the changing educational landscape that focuses on testing and 
accountability in schools, questions arise about whether emotive narratives, such as Hope's stories of the dead baby bunny, are valued or marginalized within schools.

This study illustrates the critical role that writing about local, meaningful, and emotive experiences has in motivating children's writing, developing healthy relationships within families, and maintaining and sustaining one's mental health in stressful and changing circumstances. While the findings presented here are not generalizable to all families, they do suggest that children's small stories as represented by their written artifacts evolved into narratives that gave life to and provided tangible evidence of the children's experiences in the world. As Freire (2003) argued, children's understandings of the world around them are critical driving forces to understand the written word.

\section{References}

Baghban, M. (2007). Scribbles, labels, and stories: The role of drawing in the development of writing. Young children, 62(1), 20-26.

Bamberg, M., \& Georgakopoulou, A. (2008). Small stories as a new perspective in narrative and identity analysis. Text \& Talk-An Interdisciplinary Journal of Language, Discourse Communication Studies, 28(3), 377-396.

Barton, D., \& Hamilton, M. (1998). Local Literacies: Reading and writing in one community. New York: Routledge.

Bomer, R. \& Maloch, B. (2012). Diverse local literacies and standardizing policies. Language Arts, 90(1) 44-50.

Brandt, D. (2001). Literacy in American lives. New York: Cambridge University Press.

Burton, C. M., \& King, L. A. (2004). The health benefits of writing about intensely positive experiences. Journal of Research in Personality, 38(2), 150-163.

Chenoweth, N. A., \& Hayes, J. R. (2003). The inner voice in writing. Written Communication, 20(1), 99-118.

Compton-Lilly, C. (2011). Literacy and schooling in one family across time. Research in the Teaching of English, 45(3), 224-251.

Compton-Lilly, C. (2014). The Development of Writing Habitus A Ten-Year Case Study of a Young Writer. Written Communication, 31(4), 371-403.

Damasio, A. (1994). Descartes' error: Emotion, reason, and the human brain. New York, NY: Penguin Books.

Dix, T. (1991). The affective organization of parenting: Adaptive and maladaptive processes. Psychological Bulletin, 110, 3-25.

Dyson, A. H. (1989). Multiple worlds of child writers. New York, NY: Teachers College Press.

Dyson, A. H. (1993). Social worlds of children learning to write in an urban primary school. New York, NY: Teachers College Press.

Fartoukh, M., Chanquoy, L., Piolat, A. (2012). Effects of emotion on writing processes in children. Written Communication, 29(4), 391-411.

Freire, P. (2003). Pedagogy of the oppressed. New York, NY: Continuum.

Fredrickson, B. L. (1998). What good are positive emotions?. Review of general psychology, 2(3), 300.

Glesne, C. (2010). Becoming qualitative researchers. New York, NY: Pearson. 
Gregory, E., Long, S., \& Volk, D. (2004). Many pathways to literacy: Young children learning with siblings, grandparents, peers and communities. New York, NY: Routledge-Falmer.

Heath, S.B., Street, B., \& Mills, M. (2008). Ethnography: Approaches to language and literacy research. New York, NY: Teacher's College University Press.

Holquist, M. (Ed.). (1981). The dialogic imagination: Four essays by M.M. Bakhtin. Austin, TX: University of Texas Press.

Kabuto, B. (2010). Becoming biliterate: Identity, ideology, and learning to read and write in two languages. New York, NY: Routledge.

Kabuto, B. (2017). Transgenerational learning within families. Journal of Family Diversity in Education, 1(4), 46-55.

King, L. A., \& Miner, K. N. (2000). Writing about the perceived benefits of traumatic events: Implications for physical health. Personality and Social Psychology Bulletin, 26(2), 220-230.

Pahl, K. \& Khan, A. (2015). Artifacts of resilience: Enduring narratives, texts, practices across three generations. In J. Sefton-Green, J. \& J. Rowsell, J. (Eds.). Learning and literacy over time: Longitudinal perspectives (pp. 116-133). New York, NY: Routledge.

Plutchik, R. (1997). The circumplex as a general model of the structure of emotions and personality. In R. Plutchik \& H.R. Conte (Eds.), Circumplex Models of Personality and Emotions (pp. 17-45). Washington, DC: American Psychological Association.

Michell, M. (2016). Finding the “prism”: Understanding Vygotsky's perezhivanie as an ontogenetic unit of child consciousness. International Research in Early Childhood Education, 7(1), 5-33.

Miles, M.B., Huberman, A.M., \& Saldana, J. (2013). Qualitative data analysis: A methods sourcebook. London, UK: Sage.

Mishler, E. (1999). Storylines: Craftartists' narratives of identity. Cambridge, MA: Harvard University Press.

Olmstead, K. (2015). $21^{\text {st }}$ century family literacy (Unpublished doctoral dissertation). Hofstra University, Hempstead, NY.

Saldaña, J. (2016). The coding manual for qualitative researchers. London, UK: Sage.

Sorokin, P. (1943). Sociocultural causality, space, time: A student of referential principles of sociology and social science. Durham, NC: Duke University Press.

Taylor, D. (1983). Family literacy: Young children learning to read and write. Portsmouth, NH: Heinemann.

Vygotsky, L. (1986). Thought and language. In A. Kozulin (Ed.). Cambridge, MA: MIT Press. 


\section{Author Biographies}

Kathleen Olmstead, Ed.D is an Assistant Professor at the College at Brockport, State University of New York, where she teaches courses in early language and literacy as well as literacy methods. Her research interests include family literacy and early childhood education.

Bobbie Kabuto, Ph.D., is an Associate Professor at Queens College, City University of New York, where she is Director of the Literacy Program, Birth-6th Grade. She teaches courses in the areas of early language and literacy, bilingualism and biliteracy, and language and literacy in the elementary years. Her research interests include bi/literacy and socially constructed identities. 